\title{
KOM N/ERMERE - LUGTEN I GALLERIET
}

\author{
ANETTE STENSLUND
}

Jeg er for meget af en fænomenolog til at holde af andet end fænomener, jeg kan måle med min egen alen (Barthes 2004 [1980]:45).

I oktober 2012, få uger før åbningen af den første udstilling nogensinde dedikeret udelukkende til duft, mødes kurator Chandler Burr og kunstkritiker Blake Gopnik på Museum of Art and Design i New York for at diskutere det forestående show. Her følger en parafrasering af Gopniks beskrivelse af mødet:

Chandler Burr, journalist, forfatter og nu også verdens første kurator af olfaktorisk kunst, tager en flaske frem og sprøjter en smule af indholdet på en papirstrimmel. Han inviterer kunstkritikeren til at tage et snif. „Hvad siger du til den?" Strimlen dufter af „parfume, eller måske sæbe?“. Forkert svar. Burr fortæller, at han dufter et fjernt strejf af rose, men også metal og blod. Duften hedder Eau de Protection, forklarer Burr, og det er et af de mest fascinerende kunstværker, der nogensinde er kreeret. Duften blev designet som et portræt af en kvinde, som er så smuk, at der flyder roser i hendes årer. En mand stikker en metalkniv i hendes hjerte, og dette er duften af hendes blod, der løber ned ad knivbladet. Burr foreslår at tage endnu et snif. Okay, denne gang er rosen tydelig. Men stadig intet metal - måske en snert af metallisk bitterhed, men helt sikkert intet blod. Stadig hovedsageligt parfume. „Det er skørt!“ insisterer Burr. „Hvis der ikke er en alarmklokke, der ringer, når du dufter til dette, så har du et neurologisk problem. Eller også er du bare en uskolet duftfilister, lige så uimodtagelig for duftens nuancer som en parfumør kan være det over for, lad os sige, forskellen mellem syntetisk og analytisk kubisme“" (Gopnik 2012, parafraseret).

\section{Roser i årene?}

Udstillingen „The Art of Scent" blev præsenteret fra november 2012 til februar 2013. Jeg besøgte den selv i perioden, og uanset om den skildrede udveksling 
ovenfor har været ført med et glimt i øjet eller ej, peger den på en problemstilling, jeg har opholdt mig ved siden hen: Hvad er i grunden duftoplevelser? Findes der duftfilisteri? Og er „,rose-blod-og-knivblad“en mere kvalificeret oplevelse af Eau de Protection end for eksempel ,parfume“oplevelsen er det?

Lad mig være åben om mit personlige udgangspunkt: Min oplevelse lignede filisterens. Da jeg besøgte „The Art of Scent“, var der en medarrangør, som venligt introducerede mig for ærindet med en installation. Langs en væg var der anbragt duftprøver til dokumentation for en parfumes fem „skridt“ frem mod endelig komposition. Hun (medarrangøren) trak et første duftkort og rakte mig det. „Hvad dufter du?" Min umiddelbare indskydelse var, præcis som kunstkritikerens ovenfor, „parfume“, men jeg holdt inde og tog mig i stedet betænkningstid. „Rose“ tænkte jeg så, men det virkede på den anden side for ligetil. „Liljer“ lød derfor mit endelige bud. „Nah, det er rose“, korrigerede hun mig med et overbærende og lettere misfornøjet smil.

En overvejelse, jeg siden hen har opholdt mig ved, er, om udstillingsmedarbejderen overhovedet havde været interesseret $i$, hvad jeg duftede? Blev jeg i virkeligheden ikke snarere spurgt til, om jeg kunne dufte det? Det, som i duftens objektiverede bestemmelse, duftens label, der gør os i stand til at betegne og klassificere duften ud fra kendskab til dens kulturelle repræsentation eller molekylære komposition. Opgaven, jeg blev stillet, var således avanceret, for den fordrede kompetence $\mathrm{i}$ at hægte en specifik duftkvalitet på begreb, hvilket indebærer en omskabelse af ét oplevelsesmodus (duften for mig) til et andet (duftens det). „Rose“ var i dette tilfælde det rette svar. Intet andet kunne gælde, hvilket vidner om udstillingsmedarbejderens objektiverende tilgang til duft. Hun tillagde den en absolut og autonom eksistens uafhængigt af personlige opfattelser. I dette tilfælde var den objektive duft rose og ikke, som i mit eller kunstkritikerens forslag, „lilje“ eller ,parfume“. Den objektiverede duftbestemmelse holdes i den forstand på arms længde fra en individuel eksistens og næse.

I denne artikel interesserer jeg mig for duftoplevelsen som eksistensfænomenologisk forekomst. Detkommer ikke til at handle om duft som et meningsladet indtryk eller udtryk. Hvad vi henter ud af lugt i form af konnotationer, og hvad vi lægger i lugt, når vi for eksempel intenderet bruger den ekspressivt i udstillingsarbejde såvel som i en hverdagsæstetisk selvgestaltning, falder uden for artiklens ramme. Den eksistensfænomenologiske tilgang, jeg vil udfolde, søger anderledes at nå til „tingen selv“. Den vil til „lugten selv“, og den vil nærme sig duftfænomenet ved at forfølge duftens eksistentielle nærvær som et ontologisk grundvilkår. Jeg argumenterer for, at duft primært opleves i et eksistentielt nærvær. Duftens det, den objektiverende dufthåndtering, er forskellig fra en fænomenologisk duft, der involverer den enkelte eksistens. Den eksistensfænomenologiske duft kalder jeg i det videre også for „,duft for nogen“. 
Duftudstillingen „The Art of Scent" tager jeg som anledning til at diskutere lugtens ontologi. En decideret anmeldelse er derfor ikke mit sigte, og når jeg i det næste foretager nedslag i duftens univers, sker det udelukkende med interesse for at skærpe opmærksomheden omkring ubelyste eller glemte aspekter af lugt i al almindelighed snarere end med henblik på en kritik (god som dårlig) af duftkuratoriske greb. Iscenesættelsen af duft på „The Art of Scent“" kalder med andre ord på et fænomenologisk bidrag, der kan tjene til at skærpe forståelsen for, hvad eksistensfænomenologisk duft måtte være. Teoretisk hentes inspiration primært fra Martin Heideggers fundamentalontologiske filosofi. Artiklen byder på kultursociologisk og antropologisk appliceret filosofi og forholder sig på den baggrund uortodokst til Heideggers mindre empiriske, og i hvert fald ikke lugtempiriske, tilgang. Min hensigt med artiklen er at illustrere, hvordan et fænomenologisk bidrag tjener som supplement til objektiverede dufthåndteringer.

\section{ÆEstetik, duft og mellemsanselighed}

Tre begrebsrelaterede specifikationer er nødvendige indledningsvist. De handler om min reference til henholdsvis ,æstetik“, „lugt“ og „mellemsanselighed“.

I dagligdags tale refererer cestetik ofte til „det skønne“. Etymologisk kommer

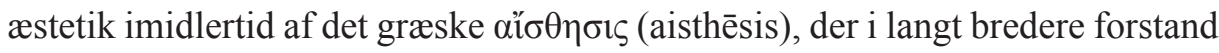
henviser til sansning, perception og sansefornemmelse. Estetik har altså oprindeligt ikke kun med det kunstneriske skønne at gøre, men behæftes med bredere hverdagslig erfaring, således som det også vil ske i denne artikel.

Med fokus på hverdagsæstetik skal det derfor heller ikke eksklusivt handle om „duft“", positivt konnoteret som vellugt. Der findes en begrænset vifte af begreber til beskrivelse af den sansning, der sker ved hjælp af lugtesansen. Foruden duft og lugt kan nævnes buket, odør, aroma, dunst, stank, em og hørm. De fleste af disse gloser er enten negativt eller positivt ladet, og det er derfor vanskeligt at finde en neutral dansk betegnelse for det olfaktoriske univers - ja, det skulle da lige være olfaktorisk (af latin olfactio, af olfacere; olere „lugte“ og facere „gøre“). De næstbedste udtryk vurderer jeg at finde i lugt, for selv om lugt kan have en negativ ladning, så er lugt trods alt mere positivt end for eksempel „stank“ og mindre positivt end „duft“. Jeg veksler mellem ordene for adspredelsens skyld og uden intention om at foretage positive eller negative ladninger. Livet både stinker og dufter, og hvornår det gør hvad, afhænger af det enkelte menneske og den kulturtilvante næse (Herz 2007:32; Classen 1992:199).

Endelig skal det understreges, at jeg betragter lugt som en sanselig kvalitet i samspil med andre sanselige kvaliteter. For eksempel er menneskets to kemiske 
sanser, lugte- og smagssansen, så tæt forbundne, at det ofte er svært at adskille dem. Hold dig for næsen, når du spiser eller drikker, og du vil erfare, hvad der er smag uden lugtesans. Adskillelsen af sanser virker altså i mange sammenhænge kunstig. Ikke engang den femdelte sansetaksonomi, som vi i vestlige samfund opererer med, er naturgiven. Det var Aristoteles, som fandt på femdelingen, fordi han ønskede at afstemme menneskets mikrokosmos til en makrokosmisk orden med fem elementer (vand, jord, ild, luft - og med alkymien quinta essentia) (Classen 1993:2). Men netop fordi Aristoteles bemærkede sansernes samspil, foreslog han også, at der fandtes en sjette sans (koine aisthēsis eller på latin sensus communis) (Howes 2009:17). At tale om fem sanser er en gængs måde at opdele vores sanseliv på, men det hindrer ikke, at man i andre sammenhænge kan tale om kun to eller måske hele 11 sanser. Antropologiske studier beretter om, at der for eksempel opereres med to sanser hos hausafolket i det nordlige Nigeria, seks sanser hos cashinahuastammen i Peru og fem ikke med Vesten korresponderende sanser blandt javanesere i Indonesien (op.cit.2). Åbenlyst udfordrer disse studier det konventionelle femdelte sensorium, og på den baggrund virker det i princippet kunstigt at dreje en sanselig undersøgelse som den aktuelle ind i en enkeltsanselig analytisk forståelsesramme. Man kan med andre ord ikke kun tale om lugt.

Frem for at gøre et stort nummer ud af afgrænsningen af lugtfænomener fra andre sansefænomener skal jeg derfor tilstræbe at imødekomme aspekter, der oftest udgør sanselige samspil. Det oplevede liv er, med et begreb hentet fra antropolog David Howes (2006), intersensorielt - fordansket kunne man kalde det mellemsanseligt. Lugt har imidlertid været en forbigået sans, hvilket har fået kunsthistoriker Jim Drobnick til at argumentere for nødvendigheden af en midlertidig „olfaktocentrisme“, således at lugt i æstetiske studier bliver dagsordensættende på linje med andre sanser (Drobnick 2006). Med et eksplicit fokus på lugt markerer jeg derfor en bevidst indlemmelse af olfaktoriske dimensioner $i$ det æstetiske studie. Jeg søger med andre ord at udvikle en „olfaktorisk æstetik“, hvilket er min betegnelse for en mellemsanselighed, der ikke forglemmer, men snarere vedrører og inkluderer olfaktorisk sansning.

\section{Forklaret duft}

Der findes dufte, mennesker ikke er i stand til bevidst at registrere, men som alligevel nærmest suger betydning til sig. Til den slags dufte hører eksempelvis genetisk bestemte kropsdufte. Hvert menneske har sin helt egen duft, unik på linje med et fingeraftryk. Vores kropslugte er påvirket af stofskifte, fordøjelse, sygdomme og sågar af humør (Hayden 1980; Fyrand 1997). Lugtens kemiske tegn går oftest menneskets næse forbi, men lader sig til gengæld registrere af kunstige 
næser (analyser med gaskromatografi og massespektrometri) eller hundenæser. Eksempelvis anvendes trænede hunde til både kræftscreening (Willis et al. 2004) og forskellige former for kriminalitetsbekæmpelse (Macrakis 2008). Feromoner er en anden slags luftbårne kemiske signaler, som kroppe ,aflæser“" og afstemmer sig i forhold til uden om vores bevidsthed (Brennan 2004:69; Vroon 1997).

Men ud over at være et kemisk tegn er lugt også et kulturelt tegn, der fungerer på såvel et bevidst som et ikke-bevidst plan. Således kender man i særdeleshed inden for markedsføring til fordele ved at bruge duftbranding i kampen om at vinde potentielle køberes opmærksomhed - uden at de bemærker det. Effektiv markedsføring har en alsidig sanselig appel, og duftindustrien er på den baggrund blevet et milliardforetagende. For eksempel indikerer test af parfumerede og uparfumerede sko, at kunder kvalitets- og prisestimerer duftende sko højere end ikke-parfumerede sko (Lindstrøm 2005:111). Lugt øver uomtvisteligt en ekstraordinær indvirkning på menneskers stemningsleje (herunder købetrang), og fysiologiske forklaringer peger på, at det er lugtesansens meget direkte forbindelse til det limbiske system - det center i hjernen, der influerer følelser og hukommelse der er en del af årsagen til lugtens kraftige indflydelse på menneskers følelsesliv (Herz 2007:3; Stoddart 1992:37).

Også duft, vi mere bevidst forholder os til, kan fungere som eksplanandum ladet med meningsfulde budskaber. Sociologer og antropologer er eminente til at foretage meningsafsøgende analyser af det sociale liv - også af det liv, der lugter! „To sense [...] is to make sense.“ Sådan indleder sociologerne Waskul og Vannini (2008:53) deres undersøgelse af de sociale budskaber, som lugt bibringer. Det er klart, at olfaktorisk sansning er en uadskillelig del af det sociale liv. Som Georg Simmel skrev: „Det sociale spørgsmål er [...] et næsespørgsmål“ (Simmel 1992: 734). Simmel havde øje for, hvorledes lugt var indrulleret i moralske spørgsmål, og han iagttog, hvordan sociale antipatier og sympatier i antisemitiske rørelser blev reguleret med reference til lugt, hvor fremmede, foragtede eller moralsk fordømte mennesker blev stigmatiseret som lugtende (op.cit.733). Simmel havde desuden øje (og næse) for, at dufte bruges til selvgestaltning på linje med beklædning og anden æstetiseret udsmykning. Vi fjerner nogle former for dufte og tilsætter andre for at signalere, hvem vi gerne vil være. Duft som „,impression management“ er også vel belyst i andre sociologiske og antropologiske studier (se blandt andet Largey \& Watson 1972; Low 2006; Waskul \& Vannini 2008). Flere interessante Peirce-inspirerede studier har desuden undersøgt lugt som tegn, det vil sige som et perceptionsindhold, der tiltvinger sig fortolkning (se blandt andet Gell 1977; Krogstad 1989; Katz 1996). Disse olfaktoriske kulturstudier viser, hvorledes lugt som et objektivt defineret substantiv er indlejret i et semiotisk indeksikalt kulturelt system. 
I denne artikel interesserer jeg mig mindre for duftens betydning og mere for dens eksistentielle ontologiske fundament. Analysen hæver sig, til forskel fra betydningsorienterede forklaringsmodeller, således ikke over fænomenoplevelsen, sådan som den viser sig for den enkelte. I forsøget på at sætte forklaringer i parentes får den aktuelle fænomenologiske analyse en nærmest impressionistisk karakter. Artiklen vil „til lugten selv“. Den vil nærmere olfaktorisk æstetik, sådan som den opleves for den enkelte eksistens.

\section{Noget i luften, der begrænset begribes}

„The Art of Scent“" må betragtes som et kærkomment initiativ til at sprænge grænserne for museumsudstillingers oftest primært visuelle æstetik. Udstillingen bød på en smuk minimalistisk oplevelse, hvor duft dog ikke uproblematisk syntes adskilt fra visuel, auditiv og haptisk æstetik - en øvrig æstetik, der normalt akkompagnerer parfumeduft i form af flakoners materialitet, tyngde og kunstnerisk svungne former, indpakningsæsker i alskens afarter og reklamekampagner med farver, billeder, lyd og symbolik. Alt dette var udeladt. Duftenes uhåndgribelige, usynlige, lydløse og blot for næsen perciperbare stoflighed blev således modigt forsøgt udstillet inden for rammerne af en arkitektonisk hvid kubus. Modigt, vil jeg mene, med tanke på, hvordan ,the white cube“ inden for kunsthistorien har været kritiseret for sin sterile og ikke mindst duftløse kulisse, der traditionelt har tjent til at rømme udstillingsmiljøet for al anden end visuel æstetik (Celant 1996; Drobnick 2002). Det er mit indtryk, at man på „The Art of Scent“ havde forsøgt at udstille dufte ,i sig selv“ og på egne præmisser, men udviskningen af andre sanselige indtryk i kombination med et tekstmateriale endte måske i virkeligheden med at „overdøve“ duftene. Igen: Jeg er ingen kritisk anmelder, men nødvendigheden af en kritisk fænomenologisk refleksion trænger sig på.

I et stort bart rum blev 12 parfumer spredt fra hver sin fontæne indbygget $i$ væggen. Ved siden af hver duftfontæne blev der kastet små tekster på væggen ved hjælp af en projektor. Teksten forsvandt og kom igen med jævne mellemrum - en raffineret visuel detalje, der bidrog til at understrege duftens flygtighed. Teksterne bestod af flere slags informationer: Kemisk fagterminologi oplyste om for eksempel ætyl vanillin, aldehyd, dihidromyrcenol, kumarin og ætylmaltol ofte nævnt i kombination med kunstlitterære stilarter som romantisme, modernisme, abstrakt kunst, realisme og hyperrealisme. Her et eksempel fra parfumør Ernest Beaux' Chanel No 5:

Beaux, en eksemplarisk modernist, opbyggede en traditionel fransk blomstret duft, derefter brød han med den tradition ved at svøbe den i [...] aldehyder (Burr 2012). 
Duftenes semiotiske indeksikalitet var tydeligt præsenteret. For eksempel kunne man læse om Aromatics Elixir (1971), at den var ,fyldt op med skygger og ornamentering“, Untitled (2010) derimod var „grov og rå“, og så var der den mere poetiske af slagsen, hvor Osmanthe Yunnan (2006) blev udlagt som et olfaktorisk bud på „den diafane lyskvalitet [...] blotlagt for ornamenter og excesser, der spreder sig som lys“ (Burr 2012). Tekstbeskrivelserne illustrerer det komplekse abstraktionsniveau, som olfaktorisk æstetik kan håndteres på kulturelt. Det er der intet odiøst i, men udstillingens abstraktionsniveau illustrerer til gengæld, at semiotisk fortolkende tilgange til olfaktorisk æstetik naturligvis ikke kan stå alene. Det uddyber jeg nedenfor.

\section{Abstrakt - og dog så begrænset?}

Som det olfaktoriske geni Grenouille, hovedfiguren i Patrick Süskinds roman Parfume, minder os om, er der et tydeligt misforhold mellem verdens lugtmæssige rigdom og sprogets armod. Således besværes Grenouille for eksempel over brugen af et så forenklet begreb som ,røg“", der skal begribe „et lugtmønster sammensat af hundrede enkelte dufte, som forvandle[s] hvert minut, ja hvert sekund og blande[s] til nye enheder" (Süskind 2005:26). Lugt byder på mere, end ord kan begribe. „Mit sprogs grænser er ikke min verdens grænser,“ skriver Howes (2006:162), og lugt er et enestående eksempel på livets ekstralingvistiske kvaliteter.

Kategoriseringer af fænomener - in casu lugt-,,forstyrrer" mere simple oplevelser (Schmitz 1968:33). Ord tilretter med andre ord meget let vores lugtoplevelser, hvilket ofte sker reduktivt, fordi enhver forstående udlægning af duft giver et praj om, hvad vi olfaktorisk skal afsøge. „Kan du dufte det?“'Konfronteret med duften af for eksempel Eau de Protection dufter kunstkritikeren uden detailviden „blot“" parfume, men får han siden hen et praj om, at han i duften kan hente blod, roser og metal, påbegynder en ny duftoplevelse, hvor duften afsøges for sådanne spor. Og resultatet: „Okay, denne gang er rosen tydelig. Men stadig ingen metal - måske en snert af bitterhed.“ I en sådan aflæsning af duft rettes opmærksomheden langsomt ind, og man forstår at hente dybere budskaber ud af duften snif efter snif. På „The Art of Scent“ havde man således valgt at præsentere objektiveret duft - duft, der var blevet kunstperiodisk og kemisk „fordøjet“ frem for at blive præsenteret på en måde, som tillod den enkelte museumsgæst først at gøre sig egne oplevelser. Betingelsen for, at et objektivt kriterium for lugt kan opretholdes, må naturligvis være, at lugten eksisterer uafhængigt af eksistensen og vice versa. Således forudsættes en subjekt-objekt-dikotomi, som, minder Heidegger om, fejlagtigt er blevet gjort til det ontologiske afsæt for al moderne vestlig videnskabelig bedrift (Heidegger 1972:15-27). Det er nødvendigt at få 
Heideggers ontologiske skel mellem vulgærontologi og fundamentalontologi på plads, inden jeg i næste afsnit tager fat om den fænomenologiske lugt.

\section{Lugtens fundamentalontologiske tingslige væren}

Vulgærontologien er ifølge Heidegger et fejlantaget ontologisk udgangspunkt - heraf det vulgære - og forholdet, der problematiseres, handler om, at det er en abstraktion at kategorisere fænomener på afstand fra resten af den verden, de indgår i. Kategoriserende udlægninger er objektiveringer, der behandler fænomener som varende for en vaeren. Der findes altså en mere grundlæggende ontologi end den, vi almindeligvis regner for at være grundlæggende - heraf udtrykket fundamentalontologi, som Heidegger kalder sin filosofi (Heidegger 1972:13). Lad mig applicere denne grundtanke på lugtfænomenet. Lugtens værende er alle former for kulturspecifikke gængse lugtbestemmelser (molekylære, kunst- og genrebevidste udlægninger er eksempler). Det vil sige lugtkonventioner, der ovenfor også er omtalt som lugtens det. Lugtens værende er imidlertid ikke sammenfaldende med dens veren. Således er der ontologisk differens mellem lugtens væren og dens værende. Lugtfænomenologien, som jeg her er i færd med at udvikle, interesserer sig først og fremmest for lugtens væren. I fokus står en tænkning af selve det vilkår, at lugt overhovedet $e r$, og af, hvordan lugt er som en væren-i-verden, hvilket vil sige uadskillelig fra omverdenen. Lugtens det, dens værende, er ganske vist interessant at belyse ud fra en kultursociologisk eller antropologisk optik, hvor lugtens indlejring i kulturelle betydningssystemer kan iagttages. Men sådanne studier handler om lugt på ontisk niveau, det vil sige et niveau, der bestemmer, udpeger eller måler lugt som vaerende udtryk for dette eller hint. Objektiverede bestemmelser af lugt påstempler så at sige lugt en etiket og lægger således afstand til lugtfænomenet i dets kompleksitet. „Hug en hæl og klip en tå“ - nok lader lugt sig etikettere, men spørgsmålet er, om skoen (og etiketten) passer?

I det følgende behandles lugt som en „ting“. Den er ingen ting i dagligdags moderne forstand, men den er en ting i Heideggers forstand. Heidegger gør en væsentlig pointe ud af at skelne mellem ting og objekter. Hvor ting står ,selvstændigt" som noget i sig selv (Selbststand er ,tingene i sig selv"), er objekter bestemt ved deres placering over for os (Gegenstand) (Heidegger 1954:59). Objektet er altså det, der bliver genstand for refleksion, og som vi søger at forholde os til i meningsfulde termer. I forhold til lugt er lugtobjektet det samme som et lugtverende (jf. lugtens det). Lugt som „ting“ er til gengæld, hvad jeg også kalder for lugt for nogen. At objektivere lugt kræver en abstrakt tilgang til lugt. Problemet opstår, når denne abstraktion bliver den mest naturlige. I sådanne tilfælde kan vi ikke længere se kunstigheden i det kunstige greb, og den mest umiddelbare måde 
at opleve den, i dette tilfælde, olfaktoriske verden på forglemmes. Med denne overvejelse bevæger jeg mig videre til en undersøgelse af det fænomenologiske fundament for olfaktoriske oplevelser.

\section{Væren er ikke tilstedeværelse}

Ambitiøse såkaldt „rige“ museumsudstillinger ønsker ofte med et æstetisk virke at ramme besøgende. De vil berøre og vedrøre i kraft af deres presenceeffekt (Arnold \& Söderqvist 2011; Söderqvist, Bencard \& Mordhorst 2009; Mordhorst 2009). Det presencebegreb, der her refereres til, er hentet fra Hans-Ulrich Gumbrecht, som igen udarbejder begrebet med reference til Heideggers værensanalyse (Gumbrecht 2004a:66). Gumbrechts presenceanalyse tjener til at bringe mennesket tilbage i kontakt med tingene selv (op.cit.46,56), og derfor skal jeg i dette afsnit se nærmere på presencebegrebets potentialer for også at nærme sig lugtfænomenet. Lad mig på forhånd afsløre, at disse potentialer skal vise sig ikke at være uden begrænsninger, hvilket derfor fører til en begrebsjustering, der skal hjælpe med til at komme nærmere lugten i galleriet. Men først et tilbageblik på presencebegrebets angivelige fundament.

For bestemmelsen af værensspørgsmålet retter Heidegger opmærksomhed mod

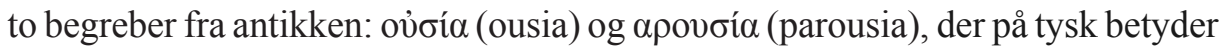
„Anwesenheit“ (Heidegger 1972:25). På dansk kan Anwesenheit oversættes til tilstedevcerelse eller ncervaerelse. Ousia er afledt af verbet einai (at være) og betyder ,væren“ i forståelsen „,det, der er“, som regel i betydningen „ejendom“, fordi „det, der er“ altid er der for nogen. Præfikset „para“ kan betyde „,ved“, „,ved siden af“ eller „hos“, og parousia kan således oversættes til „,ved-væren“ eller „hos-væren“(Liddell-Scott-Jones Lexicon). Det er imidlertid ikke helt ligegyldigt, om man vælger den ene eller den anden oversættelse, for det, der er ved siden af væren, er jo ikke lige så meget en del af væren, som det, der er hos væren.

Christian Rud Skov har i sin danske oversættelse af Heideggers Sein und Zeit korrekt oversat Anwesenheit til nærværelse. „Det værende bliver grebet i sin væren som 'nærværelse'“, skriver han (Heidegger 2007:45). På engelsk glider „nærværelsen“ imidlertid let ud af sproget, fordi tilstedeværelse og nærværelse falder sammen og bliver til „presence“. Gumbrecht henviser netop til presence i sine engelske tekster, men fastholder også presencebegrebet i sine tyske udgivelser, idet han anvender ordet „Präsenz“(Gumbrecht 2004b:201). Dette har konsekvenser og sker på bekostning af nærværet, hvilket jeg her skal vise.

Presence er afledt af det latinske verbum prae-esse (prae = ,foran“, , ,esse“ = ,at være“) og betyder det, der er ,foran os, inden for rækkevidde og håndgribeligt for vores kroppe“ (Gumbrecht 2004a:17). Presence (fremover kaldet tilstedeværelse) 
og Anwesenheit (nærværelse) kommer med tiden til at betyde nogenlunde det samme, men det er værd at være opmærksom på begrebernes forskellige etymologier, for heri ligger grunden til den forvanskning af nærværelsesbegrebet, jeg mener, der sker, når det oversat til tilstedeværelse ikke længere i samme omfang involverer en menneskelig eksistens (fænomenet for nogen), men i stedet lader fænomenet stå ved siden af eller over for eksistensen. Det tilstedeværende bliver en ved-væren - et objekt, der har mistet sin tingslighed i Heideggers forstand, og således er det graden af eksistensinvolvering, der bliver sat på spil, når de to begreber bruges synonymt.

Gumbrecht sætter tilstedeværelsesbegrebet op som idealtypisk kontrast til et meningsbegreb og yder herved et vigtigt epistemologisk bidrag i påpegningen af, at fænomener udgør mere end mening (se Stenslund 2012). Tilstedeværelsesbegrebet kan imidlertid bruges til at påpege, at lugt er andet og mere end repræsentation. Med dets ekstralingvistiske sensibilitet muliggør begrebet, at der kan rettes opmærksomhed mod netop lugt, der bare er. Begrebets berigende påmindelse til trods synes den analytiske optik fortsat ufuldkommen, for lugt er ikke blot til stede eller mere grundlæggende og med Graham Harmans ord: væren er ikke tilstedeværelse“ (2007:1, min fremhævelse). Søges lugten tilnærmet, fordres en rettelse i forhold til forståelsen af Heideggers eksistentielle værensbegreb. Jeg foretager derfor en justering med argumentation for lugtens nærværelse nedenfor.

\section{Mere end til stede}

„Alle afstande i tid og sted skrumper ind.“ Sådan starter Heidegger sit essay om tingen (1954:167). Problematiseringen handler som udgangspunkt netop om fænomenets tilstedeværelse - en afstandsdebat, der, som vist, fortsættes den dag i dag blandt andet med Gumbrechts tilstedeværelsesbegreb. Men lad mig med Heidegger minde om problemets egentlige kerne:

Den febrilske afskaffelse af alle afstande bringer ingen nærhed; for nærhed består ikke af afstandes korthed. Hvad der er tæt på os, når det gælder afstand [...], kan forblive langt væk, og hvad der synes uoverskueligt langt væk, når det gælder afstand, kan være tæt på. Kort afstand er ikke i sig selv nærhed, og stor afstand er ikke fjernhed (ibid., min oversættelse).

På museet kan man som regel komme tæt på ting. Det er i hvert fald oftest ønsket både fra kuratorers og besøgendes side. Kun montrer og afskærmning hist og her skaber distance. En simpel præventiv foranstaltning, der skal værne om tingenes uskadthed. Det er i denne fysiske og rumlige sammenhæng, at man 
inden for museologien er begyndt at interessere sig for tilstedeværelsesbegrebet (se fx Mordhorst 2009). Nok er der ikke altid adgang til tingene på så tæt hold, at de kan røres, men nærhed i form af fysisk distance synes alligevel at være en mindre forhindring for museumsoplevelsen. Som Heidegger påpeger, kan man stå nok så tæt uden at føle sig nær, og man kan føle sig nær på afstand. Den museale udfordring ligger derfor, vil jeg hævde, snarere i oplevelsen af nærvær.

Lugtfænomenet kan hjælpe med at tydeliggøre, hvad der er på spil i forhold til tilstedeværelsens utilstrækkelighed. Lugt er nemlig til stede overalt i form af lugtmolekyler, og i denne materielle form kommer lugten tæt på os. Ikke blot omgiver den os, den trænger med hver eneste indånding ligefrem ind i os: ind i næsen, ned gennem svælget, forbi strubehovedet til bronkier og lunger. Men uanset hvor tæt vi kommer i fysisk kontakt med lugt, kan den stadig undvige vores opmærksomhed. På „The Art of Scent" trængte dufte sig fysisk på (som tilstedeværende), men alligevel oplevede jeg at opholde mig mere ved tekstmaterialet om duften, end jeg dvælede ved duften selv. At dufte er tilstedeværende, er derfor ingen garanti for, at de viser sig i deres nærvær. Det samme gælder i princippet for andre æstetiske fænomener; vi kan være omgivet af støj uden at studse over det eller lede efter brillerne, mens de sidder i panden. Med reference til Joseph Albers skelner den tyske filosof Gernot Böhme mellem faktuelle og aktuelle fakta forstået som henholdsvis realitet og virkelighed (Böhme 2001:25). Til faktuelle fakta hører genstande (objekter) og deres objektive bestemmelighed. Faktuelt kan lugt bestemmes som tilstedeværende molekyler eller kulturelle tegn, men aktuelt former lugt sig også affektivt for den enkelte eksistens, og denne virkelighed er ikke nødvendigvis i overensstemmelse med den objektive lugt. Jeg skal derfor afslutningsvis illustrere, at eksistensen, når det kommer til en fænomenologisk analyse, altid vil være en del af fænomenet selv. Som følge heraf anskueliggøres nærværelsen som uomgængeligt moment i æstetiske oplevelser, herunder lugtoplevelser. Lugt står nemlig aldrig i sin umiddelbarhed over for os (prae-esse), men viser sig snarere at inkludere den menneskelige eksistens.

\section{Lugt nær væren}

Objektivt kan lugt bestemmes og måles - sådan da, for selv inden for naturvidenskaben består olfaktorisk sansning af en del ubekendte forhold. Olfaktorisk anatomi er for eksempel ikke ens hos alle mennesker. Hverken antallet af aktive receptorer, der opfanger signaler om duft fra miljøet, tykkelsen af det slimhindelag, der beskytter dem, eller de neurale forbindelser til hjernen er ens for alle (Keller et al. 2007). Om vi derfor reelt lugter det samme, når vi lugter 
til, hvad der objektivt bestemmes som samme lugt, vides ikke med sikkerhed. Trods alt synes det dog lettere at bestemme objektiv lugt end fænomenologisk lugt, for eksistensen, hvorpå næsen rent faktisk hægter sig fast, øver afgørende indflydelse på lugtoplevelsen. Oplevelsen påvirkes for eksempel af vores stemning, erfaringshorisont og forventninger. Lugtassociationers virke er således et ejendommeligt fænomen, hvor for eksempel et enkelt snif af en genkendelig lugt kan sende os direkte tilbage i tid og sted - en slags olfaktorisk tidsrejse, der bestemmes af individuelle biografier, og som derfor har forskellige afsæt og destinationer. Marcel Proust har vundet berømmelse for sit eksempel på dette mémoire involuntaire. Her var det aromaen fra en enkelt beskeden petit madeleinekage, der dyppet $i$ te fik en barndomsscene til at rejse sig fra koppen (Proust 1913:27-51). Til test købte jeg en dag en hel pose af de muslingeformede kager, men personligt rokkede de mig ikke en millimeter ud af stedet. I Heideggers hermeneutisk-fænomenologiske udlægning af eksistensens omverdensoplevelse finder jeg et bud på, hvorledes eksistensen altid medtænkes i det nærværende fænomen. Denne klassiske fænomenologiske tænkning, vil jeg mene, kan fortsat yde et essentielt fundament for nyere fænomenologi, og som det vil fremgå, kan den også yde et vigtigt bidrag til studiet af olfaktorisk æstetik. Lad mig derfor skitsere, hvad omverdensanalysen handler om.

Når mennesker gør sig erfaringer med noget, er det ifølge Heidegger ikke sanselige indtryk, der nødvendigvis rammer os først. For eksempel vil jeg ikke nødvendigvis, når jeg støder på ting i mine omgivelser, forholde mig til deres lugt. Snarere erfarer jeg omverdenen umiddelbart som en helhedserfaring uden at dechifrere farve, form, lugt, lyd osv. Ydermere er helhedserfaringen altid meningsbåret og står således ikke i et antitetisk forhold til menneskets intuitivt hermeneutiske væremåde. Det mest primære oplevelsesmodus overhovedet er at opleve fænomener som noget (Heidegger 1972:149, 1982:93, 1987:71). Det betyder, at fænomener relateres hermeneutisk intuitivt til ens egen eksistens (op.cit.117). „Betydningsfuldhedens som“ er et ganske umiddelbart og ufortænkt oplevelsesmodus, der udspringer af menneskets kulturelle erfaringshorisont. Afgørende for oplevelsen er derfor, hvem der oplever. Heidegger illustrerer med reference til oplevelsen af en talerstol:

[I] auditoriet ser jeg talerstolen. [...] Hvad ser 'jeg'? Brune overflader, der retvinklet skærer hinanden? Nej, jeg ser noget andet. En kasse med en mindre kasse stillet ovenpå? Overhovedet ikke, jeg ser talerstolen, som jeg skal tale fra. [De studerende] ser talerstolen, hvorfra der tales til dem [...]. I den rene oplevelse ligger der ingen funderingssammenhæng, [...] som om jeg først så brune, krydsende overflader, der siden hen gjorde det ud for at være en kasse, så skrivebord, så akademisk talerstol og kateder. Som om jeg kunne klæbe det katederagtige på kassen, som var det en etiket. Alt dette er dårlig, misforstået fortolkning. En drejning væk fra 
den rene oplevelse. Jeg ser talerstolen med ét slag (op.cit.71, min fremhævning og oversættelse).

Førstehåndsoplevelser af ting er eksistens- og situationsafhængige, og de nedbrydes derfor aldrig i mindre dele, før helheden har ramt os hver især. Og oplevelsen rammer os ikke ens. Jeg oplever talerstolen i lyset af min rettethed. Du oplever den fra din. Eksemplet illustrerer fænomenoplevelsers partikularitet, men hermed ikke sagt, at alle oplevelser er komplet subjektive. Når det kommer til lugtoplevelser, har antropologiske studier tydeligt vist disses kulturelle og sociale forankring. Forskellige kulturer relaterer forskelligt til æstetiske fænomener og tilskriver dem også forskellig værdi (Bourdieu 1984; Howes 1991; Classen 1993; Howes 2003; Elberfeld 2003). Naturligvis har parfumeindustrien stor interesse $i$ at identificere sociale gruppers lugtpræferencer og også i at pejle individuelle lugtoplevelser i ens retninger, således at dufte kan sikres bredest appel og afsætning. Ved hjælp af øvrig æstetisk ledsagelse er det ikke et umuligt projekt, men som ovenfor vist, er der stadig så betragtelig stor varians blandt olfaktoriske erfaringer, at en systematiseret operationalisering må formodes at være et ufuldendt projekt. Lugtoplevelser forbliver partikulære og kan derfor blot delvist styres. I tilfælde, hvor mennesker har en nogenlunde ens kulturel referenceramme, vil der naturligvis være større sammenfald. Både Heidegger og hans studerende oplever i eksemplet ovenfor samme ting som kateder. Heidegger oplever „katederet-hvorfra-hanskal-tale“, og de studerende oplever „katederet-hvorfra-der-tales-til-dem“. Men anderledes havde det været (for nu at fastholde Heideggers eget eksempel), hvis en senegaleser var hentet ind i auditoriet:

Hvad han [...] ville se, er svært at sige. Måske noget, der har at gøre med magi? Eller noget, bag hvilket man kunne finde ly for pile og stenkast? Eller hvad der er mest sandsynligt: Han [...] ville blot se [...] et 'noget', som ganske enkelt findes? (Heidegger 1987:72, min oversættelse).

Selv hvis man ingen erfaring har med et givet fænomen, vil man stadig forstående udlægge det som noget. Senegaleserens oplevelse ligger langt fra Heideggers og de studerendes, men fænomenet er stadig behæftet med betydning som „noget-med-magi“, et „ly-for-pile“ eller „blot-et-noget“. Eksemplet skal ikke læses som udtryk for, at jo større brugserfaring man har, jo mindre vil man notere sig fænomenets æstetiske detalje. Sådan kunne det umiddelbart fejllæses, men med betoning af fænomenets kulturafhængighed må det medtænkes, at katederfænomenet er taget ud af en specifik kulturel kontekst, nemlig en moderne vestlig undervisningssituation, hvor katederets æstetiske kvalitet (for eksempel dets farve - eller lugt!) har en underordnet betydning i forhold til dets funktion (undervisningen). Havde katederet på Heideggers tid stået i Senegal, ville andre 
af dets dimensioner måske have været relevante for tingsoplevelsen. Heideggers og senegaleserens oplevelser er grundforskellige, og her ligger den centrale pointe, der kan bruges i lugtanalysen. For Heidegger pointerer, at hans egen højst individuelle oplevelse ikke må lægges til grund for en almen værensanalyse. Heideggers version er med andre ord ikke mere sand end senegaleserens. Katederets katederhed er ikke dets væsen, ligesom rosenduftens rosenhed ikke er det. Det er netop almengyldiggørelsen af detailviden (gældende blot for nogen), der uheldigt kommer til at fastholde lugtfænomener i bestemmelser på afstand fra eksistensen - vulgærontologisk som et værende. At katederbestemmelsen ikke er universel, viser senegaleserens ,ly-eller-noget-oplevelse“. Senegaleserens oplevelse er ikke-vestlig, men den er jo langtfra kulturløs. Oplevelsen er netop kulturel: Den er „noget“ for vores senegalesiske ven og „kateder“ for Heidegger. Skal noget almengyldigt derfor kunne siges om fænomenet, må det gælde for såvel senegaleseren, de studerende, Heidegger selv - og læseren af dette tidsskrift såmænd. Det almengyldige, der står tilbage ifølge Heidegger, er derfor blot fænomenets „,som, for nogen“, hvilket vil sige fænomenets betydningsfuldhed, sådan som det er for den enkelte eksistens. På linje hermed opleves duft som noget for nogen.

\section{Duft dufter i en verden, der verdner}

Når jeg ovenfor har gjort klart, at lugt lugter for nogen, er pointen ikke, at lugterfaring er rent subjektiv. En Heidegger-inspireret analyse, som den her er præsenteret, rækker ud over en skelnen mellem subjekt og objekt. Duft står ikke over for subjekter som et tilstedeværende. Nej, duft forefindes fundamentalontologisk som en del af eksistensen og vice versa. Dette er, hvad der ligger i Anwesenheit-begrebet, som jeg her har oversat til nærværelse på dansk. I en fundamental dufterfaring ,går vi op“ i duften. Vi absorberes i lugt. Vi befinder os, med et begreb hentet fra den tyske filosof Hermann Schmitz, med lugten i et „uspaltet forhold“ (Schmitz 2012:249), hvor det ikke længere giver mening at adskille lugten fra os selv. Det er her, lugt rigtigt vedrører og kommer nær. Nærværet vidner om, at vi i oplevelsen af olfaktoriske fænomener er en del af dem selv. Vi svinger med dem. Uden direkte reference til lugt formulerer Heidegger det således:

I denne oplevelse, i denne henlevelse i, ligger der noget af mig: Det går ud over mit jeg og svinger med [...]. Kun i det pågældende jegs medsvingning oplever det sit omverdenslige, hvor det verdner. Og hvor og når det verdner for mig, er jeg på en eller anden måde fuldstændigt med (Heidegger 1987:73). 
Vi har altid hver især del i lugten, og lugten har del i os, og det bliver nøjagtigt i denne medsvingning med vores omgivelser, at vi er allermest involveret $i$ verden $-o g$, vil jeg gerne tilføje, involveret i lugten. Hinsides subjekt-objekt-distinktioner kan eksistensen i en fænomenologisk analyse ikke adskilles fra en olfaktorisk verden, og derfor „verdner“ det. Det verdner i den verden, som vi er $i$ og en del af. Dér, hvor livet leves i uadskillelighed med omverdenen. Mere vedrørende og nærværende kan det vel dårligt blive? „Duft“ og „lugt“ optræder på dansk både som substantiver og som verber, men i den Heidegger-inspirerede analyse er pointen, at duft og lugt som substantiver kan træde ud af sig selv i aktivitet som verber. Det sker, når de bliver nærværende og går i ét med eksistensen, og således lugter lugt, og dufter duft allermest umiddelbart.

For at vende tilbage til den indledningsvise anekdote om duftfilisteri er filisterens (min eller kunstkritikerens) oplevelse fænomenologisk betragtet lige så meget en del af parfumeduften, som connoisseurens er det. Objektivt tog vi fejl af rosenduften, som senegaleseren tog fejl af katederet, men fænomenologisk havde vi ret, ligesom senegaleseren havde ret. Med inspiration søgt hos Heidegger kan den ene partikulære oplevelse ikke udkonkurrere den anden, og på den baggrund mener jeg at finde et demokratisk epistemologisk projekt i fænomenologien. Parfumører, kemiske analysander og andre trænede næser dufter noter af blod, rose og metal i en parfume med et sådant (objektivt) indhold. Selvfølgelig gør de det. Men hvordan lugt lugter faktuelt, fortæller intet om, hvordan den lugter aktuelt. På linje med, at katederets katederhed ikke er dets væsen, er rosenduftens væsen heller ikke rosen. Lugten er eksistensafhængig, og det er lugten af noget for nogen, der bliver dens væsen - og „noget“ holdes åbent og ubestemt i en Heidegger-inspireret fænomenologisk analyse som denne.

\section{Potentialer for fænomenologisk udstillingsarbejde}

„The Art of Scent" kan som nævnt betragtes som et ambitiøst forsøg på at frisætte parfumeduften fra en ellers konteksttynget æstetisk virkelighed. Ud fra min fænomenologiske vurdering medvirkede tekstmaterialet imidlertid til reduktivt at udstille duftenes objektiverede og betydningsladede sider. Meget handlede om at identificere olfaktorisk komposition eller budskab, men hvor var følelserne, kuldegysningerne, erindringerne og de partikulære associationer? Med andre ord, hvor var alt det, der udgør menneskets verden, den verden, der primært leves og sekundært indeksikaliseres? Kort før, jeg gjorde mit exit, stødte jeg på en gæstebog. Den var et fund fænomenologisk betragtet, for frem fra dens sider dansede den flerdimensionerede olfaktoriske æstetik, som udstillingen ellers havde været tømt for. Der var tegninger fra besøgende, der gav lugten form. Der 
var historier om parfumer, der fremkaldte partikulære minder, og der var udtryk for afsky og væmmelse såvel som fryd - alt sammen dimensioner, der hører lugten til. Gæstebogen indeholdt et fænomenologisk oplevet liv. Antropolog Brian Moeran problematiserer netop det forhold, at det hidtil har vist sig umuligt for såvel antropologer som duftleverandører at beskæftige sig med lugten selv uden at læne sig op ad symbolsprog, kommunikativt meningsindhold og visuel farverigdom (Moeran 2007:166). Men hvad er da lugten „, sig selv“, hvis ikke det er den lugt, der opleves fænomenologisk umiddelbart i simpel uadskillelighed fra sin omverden?

I stedet for at søge lugtens objektive bestemmelse kunne man vælge at spørge til lugtens „hvordan for nogen“, og det er, hvad denne artikel har gjort forsøg på ved hjælp af en fænomenologisk æstetisk tilgang. Der er ikke nødvendigvis ét konsistent budskab i parfume eller i dufte mere generelt, og vigtigere endnu er parfume og lugt ikke blot sprog, men kan netop række ud over sproget til en levet helhed (Gell 2006:405). Som Susan Sontag udtrykker det (her suppleret med min olfaktorisk æstetiske betoning i klammer):

Et [olfaktorisk] kunstværk oplevet som et [olfaktorisk] kunstværk er en oplevelse, ikke et udsagn eller et svar på et spørgsmål. [Olfaktorisk] kunst er ikke kun om noget, det er noget. Et [olfaktorisk] kunstværk er en ting i verden, ikke bare en tekst eller en kommentar til verden (Sontag 2001:21).

I denne artikel har jeg vist, at olfaktorisk æstetik involverer det enkelte menneske. Lugt er primært „,noget for nogen“, og først siden hen kan det vise sig nyttigt at gå til systematiseringer af lugtfænomener for abstraktionens og repræsentationens skyld. Men objektiveret lugt vedbliver at være en sekundærform ved olfaktorisk æstetik, i hvert fald i en Heidegger-inspireret fænomenologisk analyse. Fænomenologisk lugt kan aldrig bestemmes universelt. Centralt står med andre ord ikke spørgsmål om lugtoplevelsers korrekthed, for fænomenologisk lugt kan aldrig udlægges usandt. Mit ærinde har været at pege på det i fænomenologisk forstand mest fundamentale aspekt ved lugtfænomener. Der findes andre aspekter, og jeg gør ikke krav på fuldstændighed. Snarere appellerer jeg til, at antropologisk og sociologisk forskning fremover vil have mod på at undersøge nye, supplerende og alternative måder at forholde sig til duftstudier på. Der kan tilføjes stadig nye facetter til begribelsen af det liv, der udfolder sig olfaktorisk æstetisk.

Hvad er formålet med museumsudstillinger? Der er uden tvivl mange, og udstillinger skal ikke nødvendigvis kunne det samme. Et potentiale ved mange udstillinger er imidlertid, at de kan tilbyde besøgende en mulighed for at træde tilbage fra en kulturel dagligdag. De kan give besøgende plads til at dvæle ved omstændigheder i deres kulturelle færden, som de i deres dagligdag ikke tænker 
over-lugtomstændigheder inklusive. I artiklen har jeg udviklet et fænomenologisk perspektiv, der søger at begribe, hvorledes lugt opleves allermest fundamentalt. Der er ikke rigtige og forkerte måder at inddrage duft i udstillinger på, men der er mindre og mere fænomenologiske måder at gøre det på. Overvejelser kunne derfor gøres i forhold til at give besøgende fornemmelser for oversete aspekter ved lugt. De aspekter, fænomenologien peger på, er demokratiske i den forstand, at de frem for at søge abstraktion og objektiv betydning appellerer til den enkelte og giver en fornemmelse af, at lugtoplevelser er en integreret del af vores verden. På „The Art of Scent“ lugtede jeg virkelig parfume, inden jeg fandt frem til roser, diafane elementer, hyperrealisme m.m. Andre gæster, det gav gæstebogen i hvert fald udtryk for, blev syge, og andre igen lod sig forføre figurativt - de tegnede i hvert fald i bogen - eller lod sig fortabe i minder. Det var deres lugtoplevelser. Lugten for hver og én. Reelt kan lugt objektiveres. I rosenduften er der for eksempel ingen lilje, men det udelukker ikke, at vi rent faktisk oplever den som lilje eller andet. Af lugt kan man altså objektivt tage fejl, men fænomenologisk have ret. Således arter olfaktorisk æstetik sig i sin multifacetterede fænomenologiske kompleksitet. ${ }^{1}$

\section{Note}

1. Stor tak til Thomas Söderqvist og Inge Kryger Pedersen for vejledning. Tak til kolleger ved Medicinsk Museion, herunder navnlig Adam Bencard for gennemlæsning og gode råd. En særlig stor tak også til Mikkel Bille for kompetent og grundig feedback og til anonyme reviewere. Tak til Rasmus Sevelsted og Kirsten Jungersen for græskkyndige anvisninger og til Allan Køster for gennemlæsning. Endelig en tak til Martin Lindhardt og redaktionen for dette tidsskrift. Artiklen er en del af min ph.d.-afhandling, finansieret af Novo Nordisk Foundation, Center for Basic Metabolic Research, section for Science Communication.

Søgeord: olfaktorisk æstetik, tilstedeværelse, nærværelse, Martin Heidegger

\section{Litteratur}

Arnold, Ken \& Thomas Söderqvist

2011 Medical Instruments in Museums. Immediate Impressions and Historical

Meanings. The History of Science Society 102:718-29.

Barthes, Roland

2004 [1980] Det lyse kammer. Bemærkninger om fotografiet. København: Gyldendals Bogklubber.

Bourdieu, Pierre

1984 [1979] Distinction: A Social Critique of the Judgement of Taste. Cambridge, MA: Harvard University Press. 
Brennan, Teresa

2004 The Transmission of Affect. Ithaca \& London: Cornell University Press.

Burr, Chandler

2012 Udstillingsfolder, The Art of Scent 1889-2012. New York: Museum of Art and Design.

Böhme, Gernot

2001 Aisthetik: Vorlesungen über Ästhetik als allgemeins Wahrnehmungslehre. München: Wilhelm Fink Verlag.

Celant, Germano

1996 A Visual Machine: Art Installation and Its Modern Archetypes. In: R. Greenberg, B.W. Ferguson \& S. Nairne (eds): Thinking About Exhibitions. Pp. 371-86. London \& New York: Routledge.

Classen, Constance

1992 The Odor of the Other: Olfactory Symbolism and Cultural Categories. Ethos 20(2):133-66.

1993 Worlds of Sense: Exploring the Senses in History and Across Cultures.

London: Routledge.

Drobnick, Jim

2002 Toposmia: Art, Scent, and Interrogations of Spatiality. Angelika, Journal of the Theoretical Humanities 7(1):31-47.

2006 Introduction: Olfactocentrism. In: J. Drobnick (ed): The Smell Culture Reader. Pp. 1-9. New York \& Oxford: Berg

Elberfeld, Rolf

2003 Sensory Dimensions in Intercultural Perspective and the Problem of Modern Media and Technology. In: P.D. Hershock, M. Stepaniants \& R.T. Armes (eds): Technology and Cultural Values: On the Edge of the Third Millenium. Pp. 478-90. Honolulu: University of Hawaii Press.

Fyrand, Ole

1997 Det gådefulde sprog - om hudens kommunikation. København: Gyldendal.

Gell, Alfred

2006 [1977] Magic, Perfume, Dream. In: J. Drobnick (ed): The Smell Culture Reader. Pp. 400-10. Oxford \& New York: Berg Publishers.

Gopnik, Blake

2012 NY Museum Stages First “Scent' Exhitit”. The Daily Beast, 2. november.

Gumbrecht, Ulrich

2004a Production of Presence. What Meaning Cannot Convey. Stanford: Stanford University Press.

2004b Diesseit der Hermeneutik - Über die Produktion von Präsenz. Frankfurt am Main: Suhrkamp.

Harman, Graham

2007 Introduction. In: H. Graham: Heidegger Explained. From Phenomenon to Thing. Pp. 1-4. Illinois: Open Court Publishing Company.

Hayden, Gregory F.

1980 Olfactory Diagnosis in Medicine. Postgraduate Medicine 67(4):110-18. 


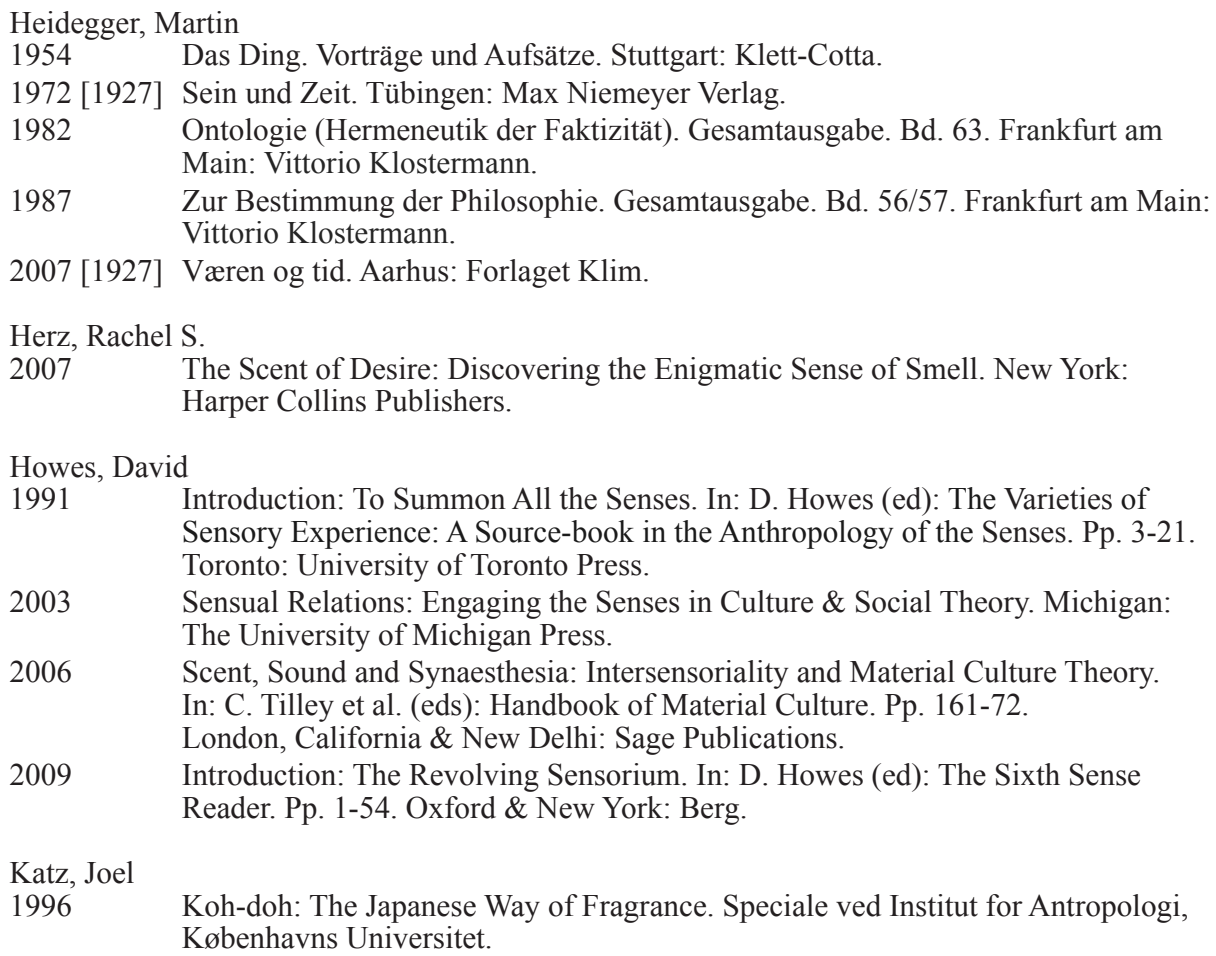

Katz, Joel

1996 Koh-doh: The Japanese Way of Fragrance. Speciale ved Institut for Antropologi, Københavns Universitet.

Keller, Andreas et al.

2007 Genetic Variation in a Human Odorant Receptor Alters Odour Perception. Nature 449:468-47.

Krogstad, Anne

1989 The Treasure House of Smell: From an "Unsensing" to a "Sensual" Anthropology. Folk 31:87-103.

Largey, Gale Peter \& David Rodney Watson

1972 The Sociology of Odors. The American Journal of Sociology 77(6):1021-34.

Liddell, Henry, Robert Scott \& Henry Stuart Jones

$1940 \quad$ A Greek-English Lexicon. $9^{\text {th }}$ ed. Oxford: Clarendon Press.

Lindstrøm, Martin

2005 Brand sense: branding for alle sanser: føle, smage, lugte, se og høre.

København: Børsens Forlag.

Low, Kelvin E.Y.

2006 Presenting the Self, the Social Body, and the Olfactory: Managing Smells in Everyday Life Experiences. Sociological Perspectives 49(4):607-31.

Macrakis, Kristie

2008 Seduces by Secrets. Inside the Stasi's Spy-Tech World. Cambridge, New York, Melbourne, Madrid, Cape Town, Singapore \& São Paulo: Cambridge University Press. 
Moeran, Brian

2007 Marketing Scents and the Anthropology of Smell. Social Anthropology/

Anthropologie Sociale 15(2):153-68.

Mordhorst, Camilla

2009 Museer, materialitet og tilstedevær. I: T. Damsholt, D.G. Simonsen \& C. Mordhorst (red.): Materialiseringer: Nye perspektiver på materialitet og kulturanalyse. Side 117-42. Aarhus: Aarhus Universitetsforlag.

Proust, Marcel

1913-27 Remembrance of Things Past. Volume 1: Swann's Way: Within a Budding Grove. New York: Vintage Books.

Schmitz, Hermann

1968 Subjektivität. Beiträge zur Phänomenologie und Logik. Bonn: H. Bouvier u. Co. Verlag.

2012 Wahrnehmung als Verhältnis. I: S. Kluck \& S. Volke (eds.): Näher Dran? Zur Phänomenologie des Wahrnehmens. Pp. 245-56. München: Verlag Karl Alber Freiburg.

Simmel, Georg

1992 Exkurs über dir Soziologie der Sinne. Soziologie: Untersuchungen über die Formen der Vergesellschaftung. Gesamtausgabe. Bd. II. Pp. 722-64. Otthein Rammstedt, Frankfurt am Main: Suhrkamp.

Sontag, Susan

2001 [1966] On Style. In: S. Sontag: Against Interpretation and Other Essays. Pp. 15-36. London: Vintage.

Stenslund, Anette

2012 Når spillet stemmer lysten. Center for Seksualitetsforskning, Sociologisk Institut, Københavns Universitet.

Stoddart, D. Michael

1992 [1990] The Scented Ape: The Biology and Culture of Human Odour. New York: Cambridge University Press

Süskind, Patrick

2005 [1985] Parfumen. Historien om en morder. København: Lindhardt \& Ringhof.

Söderqvist, Thomas, Adam Bencard \& Camilla Mordhorst

2009 Between Meaning Culture and Presence Effects: Contemporary Biomedical Objects as a Challenge to Museums. Studies in History and Philosophy of Science 40(4):431-38.

Vroon, Piet

1997 Smell: The Secret Seducer. New York: Farrar, Strauss and Giroux.

Waskul, Dennis D. \& Phillip Vannini

2008 Smell, Odor, and Somatic Work: Sense-Making and Sensory Management. Social Psychology Quarterly 71(53):53-71.

Willis, Carolyn M. et al.

2004 Olfactory Detection of Human Bladder Cancer by Dogs: Proof of Principle Study. British Medical Journal 329:712-17. 